\title{
Theresa A. Singleton
}

Slavery behind the Wall: An Archaeology of a Cuban Coffee Plantation. Gainesville:

University Press of Florida, 2015. xviii + 286 pp. (Cloth US\$74.95)

Cuba's documentary record is rich and has been explored by historians and historical anthropologists interested in the shifting contours, over nearly five centuries, of colonialism and slavery in the Atlantic world. This book by historical archaeologist Theresa Singleton is therefore especially noteworthy, as it offers important new data derived from physical evidence left by enslaved people in Cuba - the buried material remains of their rural and captive settlement. Historical archaeology has a long tradition in Cuba; see, for just one example, Lourdes Domínguez, Arqueología Colonial Cubana:Dos Estudios (1984). But Slavery Behind the Wall joins the relatively few English-language monographs on Cuban colonial archaeology.

The book presents the fruits of archaeological fieldwork that Singleton and her collaborators conducted over two decades at Santa Ana de Biajacas. Scaffolding the research conducted there is a wall that enclosed a village, framing the material world of those who lived within it. Slavery Behind the Wall is a quiet, accessibly written discussion of what objects do to the people who use them. Singleton manages to effortlessly bring into conversation the past two decades of scholarship in historical archaeology. To read this book is to know some of the discipline's theoretical and methodological concerns as well as potential future avenues of exploration.

Chapters 3-8 form the nucleus of the book, moving in scale from larger economic and historical forces down to the intimate and everyday. Chapters $3^{-} 5$ describe the Cuban coffee sector and its materialization on the built landscape. Singleton examines the way planters and visitors wished to create an earthly paradise. The irregularly placed housing and the wall erected around that housing described in Chapter 5 present evidence that departs from archaeological investigations in the rest of the Caribbean as well as in discussions of slave housing in Cuba. Housing in Cuba is generally described in terms of two categories - small slave houses (bohíos) and fortified dormitories (barracones). Owners at Cafetal Biajacas commissioned "an alternative approach that incorporated from the slaveholder's perspective the advantages of both bohios and barracones" (p. 126). A wall surrounded the village, structuring everyday life for the enslaved and concealing the harsh realities of the slavery upon which the owners' earthly paradise was built.

Chapters 6-8 analyze evidence from the material record of the enslaved to reconstruct subsistence strategies, craft activities, consumption, and the meaning of all these things in the context of enduring inequalities. In stark

(C) MARK W. HAUSER, 2017 | DOI: 10.1163/22134360-09101053

This is an open access article distributed under the terms of the Creative Commons 
contrast to slaves in the more commonly discussed examples of Jamaica, Martinique, and Guadeloupe, enslaved residents living within "the massive enclosure locked at night, had fewer money making possibilities" (p. 149). They were dependent on rations provided by the estate owner and supplemented those rations with independent production. Chapter 7 focuses on the interiority of slave life through the objects found in the houses of the enslaved. There are two points worth repeating. First is the remarkable similarity between the material worlds of the laborers and those explored on other plantations, other islands, and other colonial contexts. This provides a counterpoint to the particularistic impulses of historical archaeology. Second is the relative paucity of artifacts in comparison to those same contexts. While methodological and taphonomic processes might be at play, Singleton points to the materiality of the wall and the ability to frame the contours of everyday life.

Chapter 8 is primarily concerned with a reordering of artifacts from functional taxonomies in order to draw political implications. By way of example, Singleton discusses a common artifact found in many plantation sites, the cutlass or machete. While this tool was used to garden and harvest crops for export, it had the potential to become a weapon. Concealing such items formed an act of everyday disobedience that could be the foundation of much larger acts of resistance. The materiality of such objects affords the potential of revolt and can be placed in a dialectical relationship with the wall.

The metaphor of the wall can be extended to include the scholarly foundation upon which this research was based-bookended by the Periodo especial, during which Cuba experienced the effects of the fall of the Soviet Union, and the increased engagement of Cubans in the global economy despite the continued embargo by the United States. Today, as the embargo has begun to be relaxed, it may be easier to lose focus on Singleton's professional, ethical, and political commitments to collaborating "beyond the blockade." She has set the scene, framed the debate, and provided empirical insight into an intellectual conversation that will continue for the next three decades.

\section{Mark W. Hauser}

Department of Anthropology, Northwestern University,

Evanston IL 60208, U.S.A.

mark-hauser@northwestern.edu 